\title{
FORUM
}

\section{In Memory of the "Two Helmuts": The Lives, Legacies, and Historical Impact of Helmut Schmidt and Helmut Kohl}

\author{
A Forum with Clayton Clemens, Ronald Granieri, \\ Mathias Haeussler, Mary Elise Sarotte, Kristina Spohr, and \\ Christian Wicke
}

\author{
Introduction by Andrew I. Port
}

$M$ ost observers would likely agree, regardless of political couleur, that the Federal Republic of 1998- Helmut Kohl's final year as chancellor — was, in most respects, a much different country from the Federal Republic of 1974, the year that his immediate predecessor, Helmut Schmidt, assumed the reigns of political power. Governing successively for almost a quartercentury, the "two Helmuts"-the subject of the following forum-led the Federal Republic during what were, no doubt, some of its most turbulent years; this included the so-called German Autumn of 1977, as well as the fall of the Berlin Wall in 1989 and the protracted process of unification that followed. To mark their recent deaths (Schmidt in November 2015, Kohl in June 2017), Central European History invited a half dozen experts-five historians and one political scientist, all based in the United States, Britain, and the Netherlands — to comment on the lives, legacies, and historical impact of these two major political figures.

Each of the participants - Clayton Clemens, Ronald Granieri, Mathias Haeussler, Mary Elise Sarotte, Kristina Spohr, and Christian Wicke-was given wide latitude to approach this cluster of issues and themes in any way he or she saw fit, but the results are still, in some ways, surprising. For one, only half the contributors consider both chancellors in their initial statements, whereas the other three focus almost exclusively on Kohl. Given his role as the so-called Chancellor of Unity, this might speak to Kohl's greater historical importance-though it might also merely reflect the scholarly interests of the participants. In any event, Spohr, who recently published a major study of Helmut Schmidt as "the global chancellor," vigorously defends the legacy of the latter, arguing that Schmidt was "no less of a pioneer in international politics" than his successor. That assessment draws attention to another unanticipated feature of this forum: its focus, by and large, on the international roles of the "two Helmuts," rather than on their domestic legacies (apart from unification and "memory politics"). But this, too, is not entirely suprising or unwarranted: after all, as Clemens observes, both politicians saw their actions in that arena as their "main legacy."

Taken together, the contributions to this forum have a number of other features in common. They all go beyond the prevailing hoary stereotypes—Schmidt as a "pragmatic" and "rational" Macher, Kohl as someone driven by more "emotive" considerations; they argue, furthermore, that the approaches and 
policies of the two men were more similar, in the end, than commonly assumed. In fact, the participants seem to agree that, for better or worse, there was a great deal of continuity in the actual policies adopted by Schmidt and Kohl一that both men largely "preserved" what they had inherited domestically, while pushing Europe forward "along a path that had already been paved" (Clemens). Finally, the participants all seem to agree (with Zhou Enlai in a much different context...) that it is still too early to judge what the legacies of the "two Helmuts" will be. That issue is still "up in the air," Haeussler suggests, adding that one cannot be certain whether the policies they embraced will work in the future - though it would perhaps be more surprising if ones adopted decades ago were indeed able to do so in our rapidly changing world. It is here that Sarotte provocatively criticizes Kohl for failing to introduce "needed renovations" to the existing international system; that, she argues, lies at the crux of many of the problems that Europe faces today. Spohr rightly reminds us, however, that one must consider "how much freedom of maneuver political leaders really enjoy." Or, as the first Chancellor of Unity supposedly put it over a century and a half ago: "Politics is the art of the possible..."

\section{Initial Statements}

\section{Kristina Spohr (London School of Economics)}

$\mathrm{B}$ ETWEEN them, the chancellorships of the "two Helmuts" span nearly a quartercentury of German history. Helmut Schmidt led the country from 1974 to 1982; his successor, Helmut Kohl, served until 1998. But the verdict on their respective tenures has been very different. Kohl was seen as a bumbling provincial when he came to office in 1982 but, by the end of his second term, he had won a place in the history books as the "Chancellor of Unity" (Einheitskanzler). By the time he lost the election for what would have been his fifth term, he was hailed as the "master-builder" (Baumeister) of Europe for his decisive role in furthering the European Community's political and economic integration through the Maastricht Treaty and the introduction of the Euro. Schmidt, by contrast, came to office with a reputation for high administrative competence and intellectual prowess, but left the chancellery under a cloud. Der Spiegel spoke for many commentators when it dismissed him as a "good chancellor with a bad record"; few features of his period in office stood out as "proof of success." Schmidt, it was said, had been a mere crisis manager and "problem-solver" (Macher) who lacked broader vision, so that "little endured of historical significance."1 This has also been the verdict of many historians. ${ }^{2}$

There is no doubt that Kohl's achievements were indeed remarkable. When the Berlin Wall came down in November 1989, he quickly took command with his Ten-Point Plan, putting German unification firmly on the international agenda. Grasping the urgency of the situation, he came up with cogent ideas for accomplishing his goals: economically by exporting the deutschmark (DM) to the German Democratic Republic (GDR), and politically by absorbing East Germany into the Federal Republic via Article 23 of the Basic Law. Kohl

\footnotetext{
1 “Dreizehn Jahre geliehene Macht (I)," Der Spiegel, Sept. 27, 1982; “Kanzler Schmidt: Hoffen auf den Macher," Der Spiegel, May 13, 1974.

${ }^{2}$ See, e.g., Archie Brown, The Myth of the Strong Leader: Political Leadership in the Modern Age (London: Bodley Head, 2014), 101, 136; Ronald J. Granieri, "Building a Social Democratic Hall of Fame," H-German (Oct. 2005): http://www.h-net.org/reviews/showrev.php?id=11199.
} 
was equally adept at handling the wider international setting of German diplomacy. He managed to square the four victor powers, whose Allied reserved rights still trammeled German sovereignty: the so-called $2+4$ forum allowed him to control the process and to negotiate the final settlement of German unity with the United States, the Soviet Union, Britain, and France, from a position of quasi-equality. In particular, he propitiated the French, still fearful of German power, by agreeing to give up the DM-talisman of the West German "economic miracle"-within a new European monetary union. And he led the move to deepen Europe's political union by promoting the Maastricht Treaty of 1992.

Kohl was also very conscious of the challenges that German unity posed for the Soviet Union and its successor, the Russian Federation. At a time when the Americans were hanging back, he came up with the funds to buy Mikhail Gorbachev's support for unified Germany to remain in the North Atlantic Treaty Organization (NATO), and for the rapid withdrawal of the Red Army from German soil. Out of this came the new "Friendship Treaty" with Moscow in September 1990, which put relations on a new footing. Kohl continued this policy even after Boris Yeltsin replaced Gorbachev, pumping money into the new Russia and drawing it into the Group of Seven (G7) to help tie it to the West. At the same time, he supported Polish, Czech, and Hungarian membership in NATO as a sort of reinsurance against possible Russian revanchism. ${ }^{3}$

Kohl was intensely aware of historical precedent. In dealing with France, he aligned himself consciously with the principles of Westbindung and self-restraint laid down by Konrad Adenauer in the 1950s. In his dealings with Russia, he aspired to transcend the legacy of Adolf Hitler's war. And the media also saw him as a maker of history. After the Caucasus summit with Gorbachev in July 1990, the cover of Der Spiegel proclaimed: "Allianz Bonn/Moskau: Der Krieg ist zu Ende" (Bonn/Moscow Alliance: The War Is Over). ${ }^{4}$ Here Kohl had shown himself to be a statesman with the discernment and daring to seize the historical moment of decision. With a knowing wink to Otto von Bismarck, he told Gorbachev, "You have to grab the mantle of history." 5

Personal relationships were central to Kohl's diplomacy. He felt comfortable deploying the traditional repertoire of provincial male bonding-be it over Riesling and Saumagen (pig's stomach) at the Deidesheimer Hof in his beloved Palatinate Heimat, or sweltering in a Siberian sauna and knocking back a few vodkas with Yeltsin. Small wonder that Kohl struggled to establish a rapport with Margaret Thatcher. The Deidesheim treatment simply did not work with her: she could not get back fast enough to London. As soon as she boarded the plane, "she threw herself into her seat," her closest advisor, Charles Powell, later recalled, "kicked off her shoes and announced with a finality which was her trademark: 'My God, that man is so German."'6 Of course, Kohl's passionate Europeanness did not help relations with the Iron Lady - but, by the time Germany was celebrating unification, she was on the way out and Europe was moving into the post-Cold War era.

A decade earlier, when Helmut Schmidt was in power, the international landscape had been far bleaker and the temperature much cooler. His tenure coincided with a global

\footnotetext{
${ }^{3}$ Kristina Spohr, Germany and the Baltic Problem: The Development of a New Ostpolitik, 1989-2000 (London: Routledge, 2004).

4“Allianz Bonn/Moskau: Der Krieg ist zu Ende,” Der Spiegel, July 23, 1990.

${ }^{5}$ Helmut Kohl, Vom Mauerfall bis zur Wiedervereinigung: Meine Erinnerungen (Munich: Knaur, 2009$), 9$.

${ }^{6}$ Charles Powell, “Tales from Thatcher's foreign travels," Telegraph, April 14, 2008.
} 
economic crisis, the waning of détente, and the onset of the "New Cold War." He also had much less room for maneuver than Kohl did, having a far more tenuous hold on his own party. Schmidt became chancellor only because of Willy Brandt's ignominious fall; he did not gain a personal mandate until the elections of 1976 and, because of his predecessor's iconic status in the Social Democrat Party (SPD), he never assumed the party chairmanship. This meant that Schmidt had limited hold over his very fractious party, especially the antiAmerican pacifist left-unlike Kohl, who led the more unified Christian Democrats with a firm hand from 1973 to 1998.

Yet, within these cramped parameters, Schmidt proved remarkably creative. The man from Hamburg was a career politician at the national level in Bonn-unlike Kohl, who had never held federal office before becoming chancellor: his executive experience was confined to running the Rhineland-Palatinate from 1969 to 1976 . Schmidt, by contrast, had been defence minister (1969-1972) and then economics and finance minister (1972-1974), and he brought to bear on both offices real expertise as a public intellectual. He was not just an economist by training but also the author of two widely respected best-sellers on military strategy: Verteidigung oder Vergeltung (1961) and Stratgie des Gleichgewichts (1969). ${ }^{7}$

This intellectual hinterland served him well as chancellor. As the West struggled with the oil crisis, recession, and stagflation, Schmidt helped to establish the G7 as a forum for global economic governance, and he also played a major role in creating the European Monetary System (a kind of forerunner of the Eurozone). He was intensely aware that the world was becoming more interdependent: hence the need for enhanced cooperation to ensure stability. In security matters, his most significant achievement was the NATO "dual-track" decision of 1979, which balanced deterrence with a readiness to negotiate and disarm: "track one" committed the Alliance to stationing a new generation of American Pershing II and Cruise missiles in Europe; "track two" envisaged comprehensive arms reduction negotiations with the Soviet Union. This complex and hard-won compromise-hammered out at Schmidt's behest in Guadeloupe with the leaders of United States, Britain, and France, as NATO's three nuclear powers-was essential for holding the Alliance together at a time when it seemed in danger of falling apart. Even more important, the dual-track negotiations allowed West Germany to take a seat with other nuclear states at the top table of international politics, in what one might call a " $1+3$ " arrangement.

In the short term, the dual track was a disaster for Schmidt. Indeed, it precipitated his fall from office. His party was split over the deployment of new missiles and Kohl was able to bring Schmidt down in a vote of no-confidence. Pivotal in all this was the defection of his coalition partner and foreign minister: Hans-Dietrich Genscher, the leader of the Free Democrats, who went on to serve Kohl in the same capacity until 1992. Kohl subsequently pocketed the credit for implementing the deployment of the Pershing II and Cruise missiles in 1983 (as envisaged in the "dual-track" decision). In his memoirs, Kohl described this as "the decision of all decisions on the road to German unity." Without it, he asserted, "the Wall would not have fallen" because the Soviets would still have enjoyed nuclear superiority in Europe, and the Americans would have ultimately succumbed to Soviet pressure to withdraw from the continent. ${ }^{8}$

\footnotetext{
${ }^{7}$ Helmut Schmidt, Verteidigung oder Vergeltung (Stuttgart: Seewald, 1961); idem, Strategie des Gleichgewichts: Deutsche Friedenspolitik und die Weltmächte (Stuttgart: Seewald, 1969).

${ }^{8}$ Kohl, Vom Mauerfall bis zur Widervereinigung, 15.
} 
Schmidt naturally saw the matter differently: the "decision of all decisions" was his, not Kohl's. And, with some justice, he saw the Intermediate-Range Nuclear Forces (INF) Treaty of 1987-in which, for the first time, the superpowers agreed to reduce their armaments and even abolish an entire category of nuclear weapons - as the triumphant culmination of the "track two" agreement of 1979. Disarmament had always been Schmidt's most cherished goal. He was, as one US commentator observed in 1990, "the father of the INF deployment and godfather of the INF treaty." "Of course, there was no simple linear path from the signing of the treaty to the fall of the Berlin Wall in 1989, but defusing the Cold War in 1987 was surely an important precondition for the peaceful resolution of the German question. Arguably, then, Kohl owed a good deal more to Schmidt than he acknowledged-and so, one might say, " $1+3$ " paved the way for " $2+4$."

Cool and elegant, though sometimes prickly, Schmidt was also adept at forging close relations with other politicians, but in a very different register from Kohl's "male bonding" (Männerfreundschaften). Schmidt invested considerable effort and imagination in cultivating what he called "political friendships." 10 The deep ties he formed with individual statesmen acquired an intellectual and emotional momentum of their own-ones that outlasted his chancellorship. He was particularly close to Henry Kissinger, who described Schmidt as a "pillar in my life," and to Valéry Giscard D'Estaing, with whom he enjoyed a "belle entente" over Europe. ${ }^{11}$ But his inner circle also included Gerald Ford, George Shultz, James Callaghan, and Lee Kuan Yew. As this suggests, Schmidt thought a great deal about the importance of communication during the crisis-ridden 1970s. He always sought contact through one-on-one discussions, but he also liked small fora that facilitated direct dialogue and private, frank exchanges - keywords in his diplomatic lexicon. Summits, he believed, should not just allow leaders to articulate their national positions; they should also encourage the working out of shared interests, compromises, and projected common actions - irrespective of the quality of the personal relationships around the table. Building "trust" was important, too, especially with adversaries. To maintain predictability and to keep open channels of communication when US-Soviet relations went into deep freeze in the early 1980s, Schmidt developed for himself the role of "double interpreter" between the two alienated superpowers. In the process, he greatly raised Bonn's political stature, another asset that Kohl would later utilize in his unification diplomacy.

Schmidt's actions, and his writings since the late 1940s, also serve as a case study in the history of the "globalization of political thought as a phenomenon of reflective consciousness." 12 Schmidt was one of very few politicians in the 1960 s who anticipated a new era of global interdependence across the Cold War divide. This included an understanding of the "tripolarity" that, he foresaw, would result from the rise of China as a military and economic power. He understood more clearly than most the nexus between economic and political stability; in that sense, his interest in global economic governance was cut from the same cloth as his thinking on global security. Unlike Kissinger, who was a "realist"

\footnotetext{
9 Jim Hoagland, "Helmut Schmidt, Germany, and the World," Washington Post, Feb. 18, 1990.

${ }^{10}$ Helmut Schmidt, Weggefährten: Erinnerungen und Reflexionen (Berlin: Siedler, 1996), 251-52, 306.

${ }^{11}$ See Kissinger's address at the state ceremony for Schmidt on Nov. 23, 2015 in Hamburg: www.bundesregierung.de/Content/DE/Bulletin/2010-2015/2015/11/150-2-kissinger-staatsakt.html.

${ }^{12}$ Jürgen Osterhammel, "Globalifizierung: Denkfiguren der neuen Welt," Zeitschrift für Ideengeschichte 9 , no. 1 (2015): 5-16.
} 
focused on the balance of power, Schmidt married geopolitical with geoeconomic thinking. ${ }^{13} \mathrm{He}$ was acutely aware of the historical sensitivities of involving himself in expressly global (not just European) affairs, yet he did not shrink from using the word Weltpolitik-a word which, for many, still recalled the dangerous provocations of the Wilhelmine era and the Nazi period. When all these initiatives are taken into account and his chancellorship is properly set in a broader global context, Schmidt emerges as no less of a pioneer in international politics than Kohl. He truly was "the global chancellor."14

The political afterlife of the two men is a study in contrasts. Helmut Kohl's post-chancellorship was clouded by financial improprieties surrounding his last election campaign, and by his wife's illness and suicide. Beyond presenting his views on unification and the integration of Europe in a number of memoirs, he no longer had any appreciable impact on political debates. Schmidt, by contrast, rebuilt his reputation through speeches, commentaries, and writings - publishing almost one book a year since the mid-1980s. His editorship at Die Zeit provided him with a superb platform, of course, but his profile, knowledge, and insight as a public intellectual were also crucial in this regard. The persona was calmer now and less prickly, and, in his last years, Schmidt found himself enveloped in a wave of public affection and admiration as the "all-purpose counsellor" (Universalratgeber) of the German nation. Yet, respect for the former chancellor never quite displaced the patronizing appraisals of his chancellorship. In 2014, the newsmagazine Focus, in an essay looking back at the careers of the "two Helmuts," commented once again that Schmidt, in contrast to Kohl, had left no "historically notable" legacy. And, in its obituary for Schmidt, the Frankfurter Allgemeine Zeitung concluded that the "achievements of his political life [politische Lebensleistung] fell short of the heights attained by Konrad Adenauer and Helmut Kohl." What these judgments really reveal is the essentially parochial and partisan framework in which such appraisals tend to be formulated in the Federal Republic. A more global perspective suggests a different view. The Guardian may have shown a better understanding of Schmidt's long-term historical import in a pithily titled October 1982 article about the handover from the first Helmut to the second: "Exit a great man, enter a large one." 15

\section{Clay Clemens (College of William and Mary)}

$\mathrm{F}$ OUR men who dominated three decades of German politics all died in the last two years: Helmut Schmidt, Helmut Kohl, Richard von Weizsäcker, and Hans-Dietrich Genscher. To be sure, they came from different generations. Born in 1918, Schmidt (like von Weizsäcker) saw combat in the Wehrmacht, whereas Helmut Kohl (and Genscher) enjoyed what the younger chancellor controversially called a "blessing of late birth." But all four rose to prominence in the 1960s. And, for nearly a quarter-century,

\footnotetext{
${ }^{13}$ See Niall Ferguson, Charles S. Maier, Erez Manela, and Daniel J. Sargent, eds., The Shock of the Global: The 1970s in Perspective (Cambridge, MA: Harvard University Press, 2010), 60, 61, 358. It is noteworthy that Schmidt receives only three short mentions in this pionereering volume on the global 1970s.

${ }^{14}$ Kristina Spohr, The Global Chancellor: Helmut Schmidt and the Reshaping of the International Order (Oxford: Oxford University Press, 2016).

${ }^{15}$ Martina Fietz, "Der ewige Kampf der Altkanzler: Warum Schmidt eine politische Instanz ist—und man Kohl nicht zuhört," Focus, Nov. 8, 2014; Jasper von Altenbockum, "Macht und Eleganz: Zum Tode Helmut Schmidts," Frankfurter Allgemeine Zeitung, Nov. 11, 2015; "Exit a great man, enter a large one," Guardian, Oct. 2, 1982.
} 
the "two Helmuts," each in alliance with Genscher, headed governments in Bonn-bound by broadly similar aims and mutual loathing.

Schmidt's image has remained remarkably intact since his time in office. For most, he remains the decisive, pragmatic Macher, with unmatched skills at managing crises, both domestic and foreign; the chain-smoking intellectual with broad economic and defense expertise; and the Renaissance man, a gifted writer and artist. At the same time, few question prevailing notions of Schmidt as too arrogantly unpolitical for his own good, someone who could often not even pretend to empathize with the angst of his party's rank and file or with the unease of the broader public - though this apparent indifference barely dented the high ratings he enjoyed in opinion polls throughout his career and long afterward. By contrast, Kohl's stock has fluctuated: the eager reformer of 1970, who opened his party to dialogue with intellectuals, became the provincial buffoon ill-equipped for high office by 1980 . Both personae made way for the equally overdrawn profile by 1990 of a "folksily" shrewd global diplomat. Other images followed with dizzying speed: power-hungry autocrat clinging to office in the mid-1990s, doddering relic out of touch with the times by the time of his defeat in 1998, shady "pol" tarred by scandal a year later, principled European statesman in later life, and, at the end, pathetically mute witness to his own decline.

Verdicts on their respective legacies are equally divided. Schmidt is still generally seen as an incrementalist who rarely managed to effect significant domestic change. The impact of his experiment with Keynesian fiscal and monetary expansion in the 1970s remains a matter of debate, but those measures did not reshape German thinking on political economy, and even Schmidt ultimately backpedaled as deficits mounted. Whereas his SPD predecessor Willy Brandt idealistically pledged to "dare more democracy," Schmidt's war on domestic terror bolstered the security state. Always scornful of claims that Germany could absorb large-scale immigration from the Muslim world in particular, he did little to ready it for an era of multiculturalism, which he derided as "an illusion of intellectuals." ${ }^{16}$ (The far right's fondness for quoting him on this score must unsettle the members of his own party today.)

Schmidt's legacy in the international realm was more substantial. Due in large part to his mastery of detail, his government helped stabilize the world economy during the 1970s, but it also, and more lastingly, shaped new institutions for managing it. In her assessment of Schmidt's chancellorship, Kristina Spohr credits him with each key initiative leading to the creation of the G7 and the European Monetary System; he anticipated globalization and prepared Western countries for it. His self-assigned role as “interpreter" between Bonn's allies and Soviet-bloc leaders had more mixed results, but it, too, confirmed Germany's emergence from the second rank of world powers: thereafter, the Federal Republic could generally be at "eye level" (Augenhöhe) with its partners.

If Schmidt's legacy seems modest but secure, the scope of Kohl's impact—and, even more so, its nature-remain more disputed. On one side of the ledger is, of course, his drive to reunify Germany, an achievement on an order of magnitude all its own. Even those who credit Mikhail Gorbachev for the conditions that had made it possible-or who praise Genscher, Brandt, and others for helping to reassure the world-rarely deny that it was, above all, Kohl who single-mindedly exploited the opportunity to overcome his nation's

\footnotetext{
${ }^{16}$ Quotes from "Weitere Zuwanderung unterbinden," Focus-online, June 11, 2005; "Zitate von Helmut Schmidt: 'Wer eine Vision hat, der soll zum Arzt gehen,"” Süddeutsche Zeitung, Nov. 10, 2015.
} 
partition. Yet, if Kohl expanded the Federal Republic, how much did he actually change it? One verdict is that, despite his pledges of a Wende in 1982, his Christian-Liberal coalition trimmed Germany's social-welfare state at most (and even expanded programs supporting families), stopping short of a Thatcherite-style liberalization of the mixed economy. In the 1990s he conceded the need to foster competitiveness, but he gave in after his few cautious initiatives bogged down. A detailed evaluation of the Kohl government's record by Reimut Zohlnhöfer finds the scope of its reform "considerably more moderate" than elsewhere in Europe. ${ }^{17}$ The "semi-sovereign" Federal Republic's oft-cited institutional barriers to major policy innovations - the need for consensus among partners within multiparty coalitions, regional governments in a system of cooperative federalism, and para-public groups involved in policy implementation-were one reason. ${ }^{18}$ But those same veto players did not prevent Kohl's successor, Gerhard Schröder of the SPD, from risking, for better or worse, bolder domestic reforms. A bigger constraint on Kohl was his own nostalgic conception of the consensual, postwar German socioeconomic model as one worth preserving largely intact.

Some subsequent analyses have argued against the image of an era dominated by Stillstand (stagnation) and Reformstau (reform gridlock), citing the introduction of family benefits and the creation of an environment ministry, as well as the partial privatization of the postal system, railways, and financial markets. ${ }^{19}$ Yet, by themselves, those measures-especially when prorated over sixteen years-would convince few skeptics that Kohl fundamentally changed German socioeconomic life. Only in the East following reunification did his government truly shake things up. "Reconstruction" of the former GDR was no experiment for Kohl but, rather, the export of a proven model that would, he believed, spark another Wirtschaftswunder (economic miracle). Again, nostalgia was his lodestone. Given how conditions in former communist East Germany differed from those of the Federal Republic in his youth, the landscape there did not "blossom" as quickly or completely after 1990 as he had expected; governing by historical analogy had its pitfalls. Expanding social capitalism unquestionably belongs to Kohl's legacy, but so, too, do missed opportunities for adapting that model to new challenges. A persistent divide between a wealthy West and an East that continues to suffer from many pockets of stagnation is another legacy as well.

In other areas, the claims that this was not an era of domestic continuity are stronger. Kohl's pledge in 1982 of a "spiritual-moral transformation" (geistig-moralische Wende) remained hollow rhetoric, but the sixth chancellor's cultural impact is ever more evident: Germany's media landscape began expanding dramatically in the 1980s, mainly as a result of technological innovation but also of the government decision to end the public monopoly on television and radio. That had long been a priority for Kohl, as was his aim for an even deeper shift in thinking about German history and identity. To be sure, few critics at the time could have conceived of him truly moving intellectual debate. His obsession with the optics of historical commemoration could backfire — such as his ill-fated effort to play up US-German postwar reconciliation in a 1985 ceremony at the Bitburg military cemetery,

\footnotetext{
${ }^{17}$ Reimut Zohlnhöfer, Die Wirtschaftspolitik der Ära Kohl: Eine Analyse der Schlüsselentscheidungen in den Politikfeldern Finanzen, Arbeit und Entstaatlichung, 1982-1998 (Opladen: Leske + Budrich, 2001).

${ }^{18}$ Peter Katzenstein, Policy and Politics in West Germany: The Growth of a Semi-Sovereign State (Philadelphia, PA: Temple University Press, 1987).

${ }^{19}$ See, e.g., Günter Buchstab, Hans-Otto Kleinmann, and Hans-Jürgen Küsters, eds., Die Ära Kohl im Gespräch: Eine Zwischenbilanz (Cologne: Böhlau Verlag, 2010).
} 
despite the presence there of Waffen SS graves. Likewise, his ardent micromanaging of efforts to build modern German history museums and memorials to victims of Nazi atrocities often drew derision. But he persisted, and, in retrospect, Kohl's efforts to historicize Germany's past and "normalize" its present had a profound effect. Precisely because it lacked a rigidly narrow structure, his syncretic nationalism-Catholic and liberal-could have broad appeal and coexist with European federalism. Critics might worry that it provided cover for a reactionary conservatism and that it relativized Nazi-era crimes, but reunification and the consolidation of a "Berlin Republic" ultimately sealed his place in history.

Like most postwar chancellors, Kohl came to see his main legacy in international affairs. This rarely meant charting a new course, like Adenauer or Brandt had, but instead doing the conventional well: proving fidelity to the Western alliance and, after some backward steps, conducting businesslike relations with Germany's Eastern neighbors. His main impact lay in rebuffing pressure: from pleas by the peace movement for unilateral disarmament, to right-wing nationalist demands that the GDR regime be isolated and that the lost lands of the old Reich be reclaimed. Yet, Kohl's record of pragmatism might not, on its own, have been enough to reassure others about his rush to reunify in 1990, had it not been for his previous record on European integration. To be sure, from his use of the veto to protect German agricultural interests, to his insistence on Bundesbank terms for monetary union, he by no means blindly sacrificed German interests on the altar of European unity. Nor were most of his European Union (EU) initiatives entirely original or solo ventures. But quantity has a quality all its own: given the sheer volume of cases where Kohl put his and Germany's considerable weight behind an ever deeper, wider Union, even at a domestic price-from disproportional payments into EU coffers to abandoning the deutschmark in favor of the Euro-today's Union is arguably more his doing than that of any other single national politician. That he usually did so in close collaboration with Paris and even smaller member-states further burnishes this legacy. But his stubborn faith in "a certain idea of Europe," coupled with an indifference to detail, are also at the root of the EU's current problems - from a lack of domestic political legitimation to territorial and functional overreach. In his final days, Kohl blamed the Eurozone crisis on his successors' lack of ardor for Europe; others would trace it as well to his insistence on his "crowning theory" that the enacting of monetary union would foster the political unity needed to make the former work.

The Germany that Schmidt took over in 1974 clearly differed substantially from the one that Kohl left behind in 1998. But the main contribution both men made was to preserve what they had inherited domestically and to push Europe forward along a path that had already been paved. This was no mean feat, given the many challenges and counterpressures; moreover, a Germany wedded to consensual social-market economics and foreign partnerships was hardly the worst scenario imaginable. Both Helmuts nevertheless practiced a consensus-oriented pragmatism that deferred both the resolution of some problems and a serious consideration of new directions. Kohl, in particular, combined this status-quoist approach with cashfueled cronyism, lending credence to charges that a complacent, self-interested political elite held sway in Germany. If their heirs fail to deal effectively with the fallout from this, it may cast a less favorable light, in retrospect, on their own otherwise salutary legacies. 


\section{Mathias Haeussler (University of Cambridge)}

A S a historian of postwar European integration, I am particularly interested in the two Helmuts' seemingly different attitudes toward the European project, something that was close to both of their hearts. Schmidt and Kohl both regarded themselves as ardent Europeans, based on deeply-held convictions resulting from their personal experiences of World War II and the consequences of Germany's total defeat in 1945. During their chancellorships, they both played leading roles at key stages in the European integration process, such as the creation of the European Monetary System or the Maastricht Treaty that established today's European Union; they subsequently devoted much time and effort to the European cause in their final years as elder statesmen. ${ }^{20}$ But Kohl and Schmidt also approached the European question in very different ways, voicing their beliefs in different language and rhetoric. Taken together, their stories tell us much about the delicate relationship between European integration and the course of postwar German history.

As one of the EU's only three "Honorary Citizens of Europe" (the others are Jean Monnet and Jacques Delors), Kohl's credentials as one of Europe's major postwar statesmen can hardly be disputed. His support of the European project was a highly emotive one, grounded in his upbringing close to the Franco-German border, as well as in the death of his teenage brother during World War II. ${ }^{21}$ His cultural identity, which was strongly shaped by his religious beliefs and his attachment to his Palatinate homeland, also led the young Kohl to identify fully with the abendländ-ish spiritual core allegedly at the heart of European unification during the Adenauer years. Indeed, like his predecessor in the Christian Democratic Union (CDU), Kohl never shied away from injecting a bit of pathos into his European policies: the image of the colossal German chancellor holding hands with the French president François Mitterrand at Verdun has become deeply ingrained in public memory on both sides of the Rhine. Even his funeral in July 2017 became a bombastic celebration of Kohl's alleged contributions to the European cause, with his coffin, draped in the EU flag, laid out in the European Parliament in Strasbourg and then carried down the Rhine by boat. Though Kohl's European policies as chancellor may have lacked some strategic consistency, he was clearly not blind to the advantages of utilizing the European project for the pursuit of national interests: after the fall of the Berlin Wall, he tried to alleviate French fears of a revival of German power by embedding reunified Germany firmly within a revived and more closely integrated European Union. ${ }^{22}$

By contrast, Helmut Schmidt detested Kohl's hyperbolic rhetoric over European integration. True to his image as a sombre and pragmatic crisis manager, he frequently ridiculed the

\footnotetext{
${ }^{20}$ The book titles of their later publications are telling in this regard: Helmut Kohl, Aus Sorge um Europa: Ein Appell (Munich: Droemer Knaur, 2014); Helmut Schmidt, Mein Europa: Reden und Aufsätze (Hamburg: Hoffmann und Campe, 2013); idem, "Germany in and with and for Europe: Speech given by former Federal Chancellor Helmut Schmidt,” Dec. 4, 2011 (http://library.fes.de/pdf-files/id/ipa/08888.pdf).

${ }^{21}$ Hans Peter Schwarz, Helmut Kohl. Eine politische Biographie (Stuttgart: DVA, 2012); Hanns Jürgen Küsters, "Helmut Kohl: Architekt der europäischen Einigung? Betrachtungen zur Erforschung seiner Europapolitik," in Die Bundesrepublik Deutschland und die europäische Einigung 1949-2000. Politische Akteure, gesellschaftliche Kräfte und internationale Erfahrungen, ed. Mareike König and Matthias Schulz (Stuttgart: Franz Steiner, 2004), 221-37.

${ }^{22}$ Wilfried Loth, "Helmut Kohl und die Währungsunion," Vierteljahreshefte für Zeitgeschichte 61, no. 4 (2013): 455-80.
} 
then opposition leader Kohl as a Sonntagseuropäer, i.e., as somebody who showered flowery praise on the European cause but did nothing concrete in day-to-day practice to advance the messy and technocratic integration process. ${ }^{23}$ Though Schmidt, too, had been firmly convinced of the necessity of European integration ever since the late 1940s, his support of the European project was based more on rational calculations than on emotive beliefs: Germany's exposed geostrategic location and its unique historical burden, he thought, simply made it a necessity to embed postwar West Germany firmly into a multilateral European framework in order to make its political and economic rehabilitation palatable to its European neighbors. ${ }^{24}$ Schmidt held these convictions as deeply as his successor Kohl (and his predecessor Adenauer); yet, his role in the European integration process has thus far received comparatively little attention by historians: even today, he is remembered primarily for his statesmanship in the fields of macroeconomic policy, security, and defense. ${ }^{25}$ Schmidt nonetheless managed to leave some lasting European legacies during the troubled 1970s, not least the institutionalization of high-level diplomacy in the form of the European Council-a key part of Schmidt's more general approach to foreign policy, which Kristina Spohr discusses in her contribution.

But we should not dismiss Schmidt's highly pragmatic case for European integration prematurely. On closer inspection, the "two Helmuts" were not as far apart over Europe as it might have seemed at times. In both cases, for example, the commitment to the European project was a direct result of the chancellors' political maturation in the immediate postwar years, whether expressed in Kohl's highly emotive attachment to the European cause or in Schmidt's cool-headed calculations of postwar Germany's national interests. In this sense, they were both products of Germany's particular "1945" generation, which regarded European unification as a sharp break with Germany's troubled past and thus as a core part of the nascent Federal Republic's new postwar international identity. This sheds light on the deep interconnectedness between European integration and the German question after 1945. In different ways, both leaders believed that any postwar German strategy would have to be firmly embedded in the mantle of European multilateralism to be successful - a conviction that is still held firmly by German policymaking elites today. Indeed, it lay at the very heart of a postwar German strategy that was (and still is) frequently caught between self-restraint and self-assertion. ${ }^{26}$

In this regard, it is also telling that both Helmuts consciously put the Franco-German relationship at the center of their visions of Europe. This was perhaps understandable in the case of the Christian Democrat Kohl, a Catholic Rhinelander keen to follow the paths paved by Adenauer and Charles de Gaulle. But it was more of a surprise in the case of the North

\footnotetext{
${ }^{23}$ For a specific example, see Bundespresseamt, Bulletin 84 (July 1, 1975): 785.

${ }^{24}$ For a more extensive treatment, see Mathias Haeussler, "The Convictions of a Realist: Concepts of 'Solidarity' in Helmut Schmidt's European Thought, 1945-82," European Review of History: Revue Européenne d'histoire 24, no. 6 (2017): 955-72; idem, “A 'Cold War European'? Helmut Schmidt and European integration, c. 1945-1982,” Cold War History 15, no. 4 (2015): 427-47.

${ }^{25}$ Most recently in Spohr, Global Chancellor. Some works have even depicted Schmidt as a "reluctant" European; see, e.g., Matthias Schulz, "The Reluctant European: Helmut Schmidt, the European Community, and Transatlantic Relations," in The Strained Alliance: US-European Relations from Nixon to Carter, ed. Matthias Schulz and Thomas Allen Schwartz (Cambridge: Cambridge University Press, 2010), 279-306.

${ }^{26} \mathrm{~A}$ phrase borrowed from the classic work on the subject: Helga Haftendorn, Deutsche Außenpolitik zwischen Selbstbeschränkung und Selbstbehauptung, 1945-2000 (Stuttgart: DVA, 2001).
} 
German protestant Helmut Schmidt, who had few personal links to France and was even forced to communicate with his French counterpart Valéry Giscard d'Estaing in English. ${ }^{27}$ Yet, Schmidt also realized early on that any possible international rehabilitation of Germany depended primarily on French cooperation and goodwill-a realization that made him speak out openly against his party's anti-European stance as early as the late 1940s. ${ }^{28}$ Taken together, Kohl's and Schmidt's trajectories thus reveal that a uniquely powerful combination of highly emotional factors and shrewd political calculations held together the postwar Franco-German relationship, whatever the short-term political currents on either side of the Rhine. ${ }^{29}$ Kohl's eventual "sacrifice" of the deutschmark in support of European integration thus marked only the culmination of a constant thread in postwar German foreign policy, namely, placing the long-term political objective of FrancoGerman reconciliation and European stability well above any potential short-term economic advantages.

Schmidt's and Kohl's narratives of European integration were thus shaped by a predominantly German perspective on postwar Europe, with Franco-German reconciliation and the Federal Republic's international rehabilitation through pronounced multilateralism at the center of both. At Kohl's funeral, EU Commission President Jean-Claude Juncker correspondingly described the former chancellor as both "a German and a European patriot, because for him there was no contradiction between the two." ${ }^{30}$ An accurate description, perhaps-but also a belief that worked particularly well in the context of a defeated, divided, and semi-sovereign West Germany during the early Cold War. Indeed, the young Schmidt was not the only one to point out, as early as the 1950s, that Adenauer's occidental "small Europe" of the six (West Germany, France, Italy, and the three Benelux countries) excluded large parts of the European populace on both sides of the so-called iron curtain; indeed, many problems commonly associated with the subsequent widening and deepening of the European Union in the 1990s might well be traced back to attempts to make the embryonic structures of the six founding members work for the massively enlarged EU we have today. Even on the Western side of the former iron curtain, the 2016 British "Brexit" vote to leave the European Union offers a potent contemporary reminder that German narratives of European integration have never been universally popular among some of the older member-states either. After all, Margaret Thatcher famously dismissed the picture of Mitterrand and Kohl at Verdun as two grown men holding hands. ${ }^{31}$

With the recent passing of the "two Helmuts," it might thus be time to historicize Schmidt's and Kohl's narratives of European integration firmly within the specific historical context of postwar Germany during the Cold War, with an eye to the complex mix of

\footnotetext{
${ }^{27}$ On the Schmidt-Giscard relationship, see Hélène Miard-Delacroix, Partenaires de choix? Le Chancelier Helmut Schmidt et la France (Berne: Peter Lang, 1993); Matthias Waechter, Helmut Schmidt und Valéry Giscard d'Estaing: Auf der Suche nach Stabilität in der Krise der 70er Jahre (Bremen: Edition Temmen, 2011).

${ }^{28}$ Recently reprinted as "Ja zum Ruhrstatut: Ein frühes Bekenntnis zu Europa (1948/1949)," in Schmidt, Mein Europa, 15-24. See also Haeussler, "Convictions of a Realist," 958-59.

${ }^{29}$ Hélène Miard-Delacroix, Deutsch-französische Geschichte, 1963 bis in die Gegenwart: Im Zeichen der europäischen Einigung (Darmstadt: WBG Academic, 2011).

${ }^{30}$ European Parliament, "Press Release: Farewell to honorary European citizen Helmut Kohl," July 1, 2017 (http://www.europarl.europa.eu/news/en/press-room/20170629IPR78645/farewell-to-honoraryeuropean-citizen-helmut-kohl).

${ }^{31}$ Charles Moore, Margaret Thatcher: The Authorized Biography, vol. 2: Everything She Wants (London: Allen Lane, 2016), 389.
} 
hard-headed calculations and deeply-held personal convictions that helped shape and maintain them. This does not imply dismantling or dismissing Schmidt's or Kohl's contributions to the European cause, but rather to treat them as crucial parts of a diverse postwar discourse over European integration - an intellectual history that had always been shaped by many competing narratives and visions. ${ }^{32}$ In this sense, Kohl's and Schmidt's personal histories reveal a great deal about the role and importance of the European project in postwar Germany. But they also show how the two chancellors, like most people, were ultimately products of their particular time and place in history.

\section{Christian Wicke (Utrecht University)}

$\mathrm{H}$ ELMUT Kohl was a great European, as well as a German nationalist, who brilliantly managed to reconcile European and national identities. He should therefore be remembered not only as a historical agent who drove forward the integration of the European Union, but also for the role he played in a powerful, globalized, adaptable belief system that, over the past centuries, has increasingly sought to organize the masses into supposedly natural categories that should be both "self-determined" and entitled to a shared culture and political state.

Unification is a prime example of a nationalist event. But, in the new "Berlin Republic" that Kohl helped form toward the end of his political career, the so-called Chancellor of Unity is almost never associated with nationalism. This republic represents, in many ways, the country's journey toward "normality" that Jürgen Habermas presaged while Kohl was still in office. ${ }^{33}$ Germany has again become a nation-state with the same capital city it had between 1871 and 1945. The country remains integrated in the EU and NATO, Western organizations that developed on the "sunny side" of Cold War history. At the same time, the postnational movement in the Federal Republic, which grew strong because of the memory of Nazism, has disappeared. And the international suspicion that something is inherently wrong with the Germans also seems to have largely dissipated. It looks as if Kohl has won his historical battle for German normality!

The recent public memorializing during his burial on July 1, 2017, first in the EU parliament building in Strasbourg and then in the Speyer Cathedral, centered predominantly on Kohl's role as a great European. His efforts toward achieving European integration have been presented as inherently oppositional to an antiquated worldview of nationalism-as restraining the traditions and culture that had supposedly underlain Germany's peculiar and non-Western historical trajectory toward Nazism (i.e., its alleged Sonderweg). His instrumental role in the reunification process could thus be remembered as somehow disconnected from the underlying superideology that any nation, as an "imagined community,"

\footnotetext{
${ }^{32}$ Over the past few years, there has been growing historical interest in the narratives underlying much of the historiography on European integration. As a starting point, see Mark Gilbert, "Narrating the Process: Questioning the Progressive Story of European Integration," Journal of Common Market Studies 46, no. 3 (2008): 641-62. For an account of similar developments in European studies, see Quincy Cloet, "Two sides to every story(teller): competition, continuity and change in narratives of European integration," Journal of Contemporary European Studies 25, no. 3 (2017): 291-306.

${ }^{33}$ Jürgen Habermas, Die Normalität einer Berliner Republik (Frankfurt/Main: Suhrkamp, 1995).
} 
needs to exist. ${ }^{34}$ That is precisely the idea that Kohl himself continuously tried to suggest. He used terms such as patriotism and national consciousness as euphemisms for nationalism, which was terminologically intertwined with Nazism in Germany. Questioning the historical legitimacy of the German nation and its right to be unified was as much a taboo for him as a revival of German nationalism - as if the latter had mysteriously disappeared after 1945.

Kohl always praised the Federal Republic's integration with the West (Westbindung), a primary policy pursuit of his hero, Konrad Adenauer. His own Sonderweg-phobia drove him in his own quest to overcome Germany's alienation from the West, to reunite the nation territorially, and to foster a more positive image of its national past, which he saw as vital for legitimizing the normalization of national identity against the backdrop of Germany's "dark" history. He represented his idea of German "normality" both politically and personally-Jürgen Habermas once called him the "verkörperte Entwarnung" (the embodiment of the all-clear signal). ${ }^{35}$ And he actively engaged with forms of memory politics to rehabilitate Germans within the community of Western nations to the greatest extent possible - though without undermining the Federal Republic's foundational myth of 1945, which posited a turning point in German political culture that had finally overcome Nazism, thus paving the way for the emergence of a morally superior state. Elements of religious, liberal, and romantic nationalism, as well as national historicism, formed the foundations of his personal nationalism.

Nationalism is not only a mass ideology, but also a deeply personal one. National identities and ideas of nation may strongly differ among members of the same nation. "Personal nationalism" thus goes beyond notions of belonging and ownership, as Anthony Cohen has suggested. ${ }^{36}$ Rather, it is about the personal representations of nation that are dependent on individual socialization; the latter include class, generation, religion, region, education, and political affiliations, as well as the very personal experiences that shape one's identity and ideology. This repertoire of personal identity can be used selectively. Kohl's public self-narration as the ideal German drew on a relatively consistent self-portrait that he constructed throughout his political life. The public man presented his personal background-a Catholic from the Rhenish-Palatinate region bordering France, a member of the so-called '45er generation with a doctorate in history from the University of Heidelberg-as embodying Germany's legitimate Western identity.

Throughout (and after) his political career, Kohl displayed strong elements of religious nationalism, in which religious ideas and/or identities played an important part in the representation of nation. Joining the newly founded Christian Democratic Union already in his teenage years, and establishing himself in regional politics over the course of the 1950s, Kohl portrayed himself as genuinely Catholic — and therefore anti-ideological. Ideology was to him something extreme, like Nazism or Communism, both of which had sought to transform the individual into something unnatural and discordant with the Catholic idea of human beings as the image of God. He considered both Nazism and Communism as un-German aberrations from the "natural" course of history. Kohl explained his political

\footnotetext{
${ }^{34}$ Benedict Anderson, Imagined Communities: Reflections on the Origin and Spread of Nationalism, rev. ed. (London: Verso, 1991).

${ }^{35}$ Jürgen Habermas, "Meine Jahre mit Helmut Kohl,” Die Zeit, March 11, 1994.

${ }^{36}$ See, e.g., Anthony Cohen, "Personal Nationalism: A Scottish View of Some Rites, Rights, and Wrongs," American Ethnologist 23, no. 4 (1996): 802-15.
} 
views as flowing from his Catholic upbringing, as well as from his parents and his clerical mentors, who had introduced him to politics. He presented this background as proof that he was free of any Nazi ideology and, at the same time, that he was rooted in the culture of the West. His national hero was the first chancellor of the Federal Republic, the Catholic Rhinelander Konrad Adenauer - not the first Chancellor of Unity, the Protestant Prussian Otto von Bismarck. Not only had Germany's center of power shifted from Berlin to Bonn and from Protestantism to Catholicism: with the foundation of the Federal Republic, and with the CDU as a powerful mainstream party, a new form of German conservatism involving supranational elements had been firmly established. ${ }^{37}$ Kohl nevertheless highlighted in his $\mathrm{PhD}$ thesis on postwar political renewal in the Palatinate region the positive organizational continuities between the old Catholic Center Party of the Weimar era and his new party in the Palatinate, and he saw this continuity as characteristic of the political culture of the Federal Republic and the German nation as such. The history of his party, as much as that of his Catholic milieu, was fundamental to his autobiographical self-representation as a model German.

Kohl was also very careful during his political life, and then in retirement from politics, to represent himself as someone whom scholars of nationalism would typify as a "liberal nationalist." Yael Tamir and David Miller, for example, have argued that nationalism is useful for society as long as it remains tamed by liberal ideology. ${ }^{38}$ In studies of nationalism, an idealtypological dichotomy has sometimes been drawn between "bad," illiberal, Eastern, ethnic, cultural, and Romantic forms of nationalism, on the one hand, and "good," liberal, Western, civil, political, and Enlightenment forms, on the other. This dichotomy is particularly interesting in the German context, where it has been associated with a cultural and political Sonderweg reaching from Johann Gottfried Herder to Adolf Hitler. This dichotomy has been challenged, of course, but the way in which Kohl managed to rehabilitate supposedly dangerous traditions in German national identity by synthesizing them with more progressive ones was remarkable.

Dirk Moses coined the term '45er to describe Kohl's generation, with Helmut Schmidt, born in 1918, at one end, and Kohl, born in 1930, at the other. ${ }^{39}$ Within this (relatively) politically liberal generation, whose members valued the constitutional principles of the Federal Republic, Jürgen Habermas belonged to the "non-German German faction" (Moses's term), which sought to cultivate the postnational tendencies of the postwar era. Kohl belonged instead to the "German Germans," who felt that their fellow countrymen should renationalize their society and their past. Personal myths matter in biography, and Kohl connected his generational identity to very personal memories: toward the end of World War II, when the military situation was already hopeless for Nazi Germany, he was conscripted and sent to the Bavarian Alps to protect Hitler's Eagle's Nest retreat. Kohl fled following a British bombardment and walked all the way back to his hometown, Ludwigshafen - a walk he later described as formative, and perhaps traumatic, because of

\footnotetext{
${ }^{37}$ Ronald J. Granieri, "Thou shalt consider thyself a European: Catholic Supranationalism and the Sublimation of German Nationalism after 1945," in Religion und Nation/Nation und Religion: Beiträge zu einer unbewältigten Geschichte, ed. Michael Geyer and Hartmut Lehmann (Göttingen: Wallstein), 336-63.

${ }^{38}$ Yael Tamir, Liberal Nationalism (Princeton, NJ: Princeton University Press, 1993); David Miller, On Nationality (Oxford: Oxford University Press, 1997).

${ }^{39}$ A. Dirk Moses, German Intellectuals and the Nazi Past (Cambridge: Cambridge University Press, 2007).
} 
the violence, humiliation, destruction, and insecurity he witnessed. ${ }^{40}$ After returning, he became engaged with the reconstruction of his hometown, and, throughout his political life, Kohl would politicize such personal experiences: he was among those who had witnessed Germany's "zero hour," and he was old enough to understand what had gone wrong in his country-but too young to be personally responsible for Nazi crimes. He was also among those who had organized themselves and their society in the formative years that followed. He pithily captured these ideas, as Clay Clemens has already noted, in an oft-cited phrase from a speech he gave to the Israeli Knesset in January 1984: the "grace of late birth."

Kohl's regional identity was arguably as strong as his generational identity. He presented his regional background from the Rhenish Palatinate as inherently cosmopolitan and Western, and saw his Palatine homeland as being central to the culture of the Abendland. Kohl had strong "romantic nationalist" tendencies: he saw the German nation as a Kulturnation, fundamentally founded on a cultural rather than political identity that would survive irrespective of the "unnatural" territorial constraints of the Cold War. He presented the Palatinate as historically shaped by different ethnicities. But Germany was, in his view, reserved first and foremost for ethnic Germans, i.e., for Germans with German-speaking ancestors. He thus welcomed those from Central and Eastern Europe and the (former) Soviet Union, as well as former citizens of the GDR, but he encouraged Turkish "guest workers" to return "home," eventually. His German Heimat was not supposed to be a multicultural homeland. Mindful of a German Sonderweg, he endeavored to resolve such suspect national traditions within a supposedly positive type of "liberal nationalism." 41

Kohl was keen to be associated with the Weinstraße rather than with the Sonderweg. But his provincial appearance, combined with a pronounced European identity, should not deceive us: Kohl was a powerful political leader whose practically articulated historism, in the form of history politics (Geschichtspolitik), constituted an integral part of his conservative mission. Nations were fixed entities in history, he believed, and history was predominantly national in nature. Renouncing history would, he thought, deprive individuals of their identity. His political mission embraced the propagation of "historical consciousness" and national pride among Germans, and he was particularly concerned, in this regard, for younger generations, whose members, he feared, would perceive the abnormality of their country's division as somehow normal.

In addition to this historism, Kohl had historicist tendencies, believing that history would ultimately follow a liberal path. ${ }^{42}$ The "happy endpoint" of history was to be found in the Western model of capitalism and freedom, which would ultimately prevail over the artificial and repressive historical currents represented by the East German regime. He considered the "episode" of Nazism, as well as that of the GDR, as abberations marring the overall positive course of German history. Whereas Nazism remained very much alive in history and public memory, he perceived East Germany as an active threat in the ongoing political battle over

\footnotetext{
${ }^{40}$ See, e.g., Helmut Kohl, Erinnerungen, 1930-1994, 3 vols. (Munich: Droemer Verlag, 2004-2007), 2: 29-45.

${ }^{41}$ Christian Wicke, “A Romantic Nationalist? Helmut Kohl's Ethnocultural Representation of his Nation and Himself," Nationalism and Ethnic Politics 19, no. 2 (2013): 141-62.

${ }^{42} \mathrm{On}$ the difference between historism and historicism, see Stefan Berger, The Search for Normality: National Identity and Historical Consciousness in Germany since 1800 (New York: Berghahn, 1997), 3.
} 
the prerogative of historical interpretation. Throughout his political career, Kohl felt obliged to advance a positively connoted, teleological narrative from the medieval German empires to the Federal Republic, which is why he excluded the GDR from this storyline.

After becoming chancellor in 1982, Kohl emerged as the political head of a conservative movement of historians, intellectuals, and politicians that sought to promote a more conventional and affirmative German identity in the Federal Republic —one designed to "escape" from Hitler's shadow. This was part of the vision he referred to as a "spiritual-moral turn" (geistig-moralische Wende). The atmosphere in which the Historikerstreit of the 1980s subsequently took place must be seen in the context of Kohl's memory activism, which included plans to erect two museums in Bonn and Berlin dedicated to German history. ${ }^{43}$ The first years of his chancellorship were overshadowed, of course, by a series of geschichtspolitische scandals. The most important occurred in 1985, during his visit with Reagan to the Bitburg military cemetery. Because of such episodes, many contemporary intellectuals and historians viewed Kohl's nationalism with great suspicion. His controversial memory-politics have nevertheless had a lasting influence on the historical culture of united Germany-an important aspect of his legacy that one should not forget.

The year 1945 has nevertheless remained key for the foundation myth of the Federal Republic. Completely erasing the memory of Nazism was not desirable for the conservative mainstream during the postwar era. Kohl's aim was therefore to relativize Nazism and "desubstantiate" (entkonkretisieren) its memory - but without undermining its significance for the legitimacy of Federal Republican, and thus German, identity. ${ }^{44}$ Moreover, because of the functional importance of this turning point in national identity, it had to be carefully managed. In the 1980s and early 1990s, Kohl was thus able to emerge as the primary "trauma manager" of the German nation, walking a fine line between socially acceptable norms and inacceptable taboos. His speech at the Bergen-Belsen concentration camp in April 1985, forty years after the end of World War II, was overshadowed at the time by the Bitburg controversy (and by West German President Richard von Weizäcker's sensational, if somewhat similar, speech that spring): it nevertheless declared May 8, 1945, to be a day of liberation rather than one of defeat. This did not necessarily constitute a break in national history, in his view, but rather the end of an abnormal episode that had disrupted a generally positive past. The success of the Federal Republic in the postwar era was, for Kohl, an important step toward normality; the latter could only be achieved, however, once territorial division and the historical "culture of shame" had been overcome.

\footnotetext{
${ }^{43}$ Christian Wicke and Ben Wellings, "History Wars in Germany and Australia: National Museums and the Relegitimisation of Nationhood," in The Palgrave Handbook of State-Sponsored History After 1945, ed. Berber Bervernage and Nico Wouters (Basingstoke: Palgrave Macmillan, 2018), 431-45. Also see Andrew I. Port, ed., "Holocaust Scholarship and Politics in the Public Sphere: Reexamining the Causes, Consequences, and Controversy of the Historikerstreit and the Goldhagen Debate: A Forum with Gerrit Dworok, Richard J. Evans, Mary Fulbrook, Wendy Lower, A. Dirk Moses, Jeffrey K. Olick, and Timothy D. Snyder," Central European History 50, no. 3 (2017): 375-403.

${ }^{44}$ Sabine Moller, Die Entkonkretisierung der NS-Herrschaft in der Ära Kohl: Die Neue Wache, das Denkmal für die ermordeten Juden Europas, das Haus der Geschichte der Bundesrepublik Deutschland (Hannover: Offizin, 1998).
} 


\section{Mary Elise Sarotte (Johns Hopkins University-SAIS)}

$\mathrm{T}$ HE deaths of Helmut Schmidt and Helmut Kohl would, of course, have signalled the end of their particular geopolitical era no matter when they had happened. Coming, respectively, during the election campaign and then presidency of Donald Trump, their passing highlighted in a particularly clear way a significant contrast: between a past marked by strong transatlantic cooperation, which endured despite numerous challenges, and a present marked by the assault of the Trump administration not only on transatlantic cooperation but also on many other cooperative international ventures. Politicians and citizens on both sides of the Atlantic felt the loss of these two major historical figures even more keenly as a result. It is therefore greatly to be welcomed that Central European History has created this forum on the historical impact of the "two Helmuts," because understanding that impact is not just of historical interest: it is of urgent current necessity.

To understand in particular Kohl's contribution and its significance for today, it is useful to revisit the pinnacle of his political career: his handling of the process of German unification. Much could have gone wrong after the unexpected and unplanned opening of the Berlin Wall, and Kohl deserves a great deal of credit for providing steady leadership at a highly uncertain time. Perhaps his most relevant accomplishment was the way that, at what might arguably have been a high point of nationalist fervor-namely, the reunification of Germany in 1989-1990 - he managed to contain that nationalist moment within the existing transatlantic framework, rather than letting the processes of unification escape that framework, or even eviscerate it.

Yet, as with all major accomplishments, Kohl's success came at a price. With his intense focus on perpetuating the existing framework, Kohl missed an opportunity to make needed renovations and extensions to it. In other words, he successfully perpetuated into the postCold War era a political order constructed by, and for, divided Cold War Europe. As a result, Europe retained a de facto "front line" between EU and non-EU Europe, as well as between NATO and non-NATO Europe. What Kohl and his fellow European leaders did not do was produce plausible pan-European options, despite calls for such options from a wide variety of persons living on the Eurasian continent (i.e., not just East Europeans but also inhabitants of the former Soviet republics). As all politicians know, a crisis is a terrible thing to waste: it is one of the rare opportunities to carry out major changes. As the moment of rupture signaled by the end of the Cold War passed into history, the window of opportunity for pan-Europeanism closed.

This particular moment of rupture has been a central focus of my own scholarly research. In my earliest publications on the topic, I challenged the dominant narrative that a "new world order" had emerged after the fall of the Berlin Wall. Instead, I argued that Kohl's strategy was not one of innovation, but rather of "prefabrication." ${ }^{45}$ In other words, there was certainly a host of social, cultural, and political pressures signifying the dawning of a new world - emerging most notably "from below," i.e., on the streets of China and Eastern Europe. But no matching new world order appeared, largely because those making policy

\footnotetext{
${ }^{45}$ See, e.g., Mary Elise Sarotte, 1989: The Struggle to Create Post-Cold War Europe (Princeton, NJ: Princeton University Press, 2009); idem, "Perpetuating U.S. Preeminence," International Security 35, no. 1 (2010): 110-37; idem, The Collapse: The Accidental Opening of the Berlin Wall (New York: Basic Books, 2014); idem, "A Broken Promise?," Foreign Affairs (Sept./Oct. 2014): 90-97.
} 
"from above" preferred to "stay the course" with trusted existing, or "prefabricated," institutions.

As the dominant triumphalist narrative surrounding the end of the Cold War fades in the cold light of the current era-which is witnessing, among other tragedies, a return to the practice of changing national borders in Europe by force-other scholars have similarly begun to challenge the idea that the world entered into a fundamentally new order after 1989. In doing so, they have developed the concept of prefabrication even further. For example, Timothy Colton and Samuel Charap usefully defined the concept in a 2017 investigation of the sources of the conflict in Ukraine: "An aspect of the German reunification procedure that bears emphasis is the reliance on what Sarotte discerningly couches as 'prefab' change, a methodology hinged on the mechanical extension of existing formulas and structures rather than negotiation of mutually acceptable substitutes for them." 46

Colton and Charap's phrasing helps us to understand Kohl. The chancellor's most enduring impact stems from the choices he made in the process of unifying Germany. After being initiated by mass popular upheaval in Eastern Europe, the rapidity and nature of the German reunification process was not foreordained, but shaped, in large part, by choices that Kohl made. He chose to prioritize speed and the mechanical extension of existing formulas over the negotiation of new, potentially pan-European structures of political order. Negotiations with East German and Soviet leaders, most notably Mikhail Gorbachev, focused on the price that he would have to pay to achieve this goal, rather than on a mutual dialogue about potentially more inclusive orders. By design, Russia was left on the periphery of post-Cold War Europe. The process of German unification did not produce a new world order. As a result, it may not have been a given that a resentful Russian autocrat would one day emerge as leader - that was predominantly the function of internal Russian politics - but once one did in the person of Vladimir Putin, the persistence of a kind of de facto front line in Europe provided Putin with a ready source of grievance. After an initial period of apparent willingness to work with the West, most notably after September 11, 2001, Putin had, by the time of the Georgian war in 2008, decided on a course of violent resistance to what he viewed as Western encroachment on Russian power. ${ }^{47}$

A new challenge has now emerged: the unexpected rise of a would-be American autocrat, Donald Trump. A group of German foreign-policy experts recently summed up the significance of Trump for international relations in a widely circulated "manifesto" on transatlantic relations: "Donald Trump," they write, "is the first US president since World War II to fundamentally question the ideas and institutions of a liberal international order. He opposes this order by advocating a system of raw power and national interests." 48

When Kohl perpetuated the Cold War transatlantic order starting in 1990, he assumed that it was a constant, i.e., he assumed that the character of the American commitment to that order-regardless of whether Europeans viewed Washington's role positively or negatively, as in the era of rising anti-Americanism following the invasion of Iraq under George W. Bush-would remain largely the same. Now, in the Trump era, that assumption no

\footnotetext{
${ }^{46}$ Samuel Charap and Timothy Colton, Everyone Loses: The Ukraine Crisis and the Ruinous Contest for PostSoviet Eurasia (London: Routledge, 2017).

${ }^{47}$ Ronald D. Asmus, A Little War that Shook the World: Georgia, Russia and the Future of the West (New York: Palgrave Macmillan, 2010).

${ }^{48}$ For an English translation, see "In Spite of It All, America," New York Times, Oct. 11, 2017.
} 
longer seems to hold. Since a truly new world order-one based on pan-European cooperation, and with a defined place for Russia-failed to emerge, in large part because of Kohl's strategy, Germany now finds itself between a rock and a hard place. The perpetuated order, based on continuing reliance on the United States in a strong transatlantic partnership-most notably in the arena of international security-is unexpectedly under threat from Washington. But Kohl's drive to extend the existing Cold War institutions stunted the development of European alternatives, most notably in the field of security. As a result, as we justly celebrate Kohl's success in unifying his country swiftly and without bloodshed, we must also acknowledge in a clear-eyed manner the challenges that the policy of prefabrication left to his successors.

\section{Ronald J. Granieri (Lauder Institute, University of Pennsylvania)}

$\mathrm{H}$

ELMUT Kohl made a career out of being underestimated. Entering political life in the shadow of some of the biggest personalities of modern German political history, he often appeared overmatched. He was far from perfect, as a politician or as a human being. Ultimately, however, his political accomplishments dwarfed those of his contemporaries. At the same time, his career is marked by a central paradox. Heavy and slow in speech as well as stature, Kohl often stood accused of being stolid and unimaginative. Yet, it was precisely his lack of imagination that led to his greatest accomplishments. Raised in the post-Center Party Catholic milieu of the Palatinate, he joined the CDU as a teenager and was a consistent advocate of Westbindung, believing that the Federal Republic's role in developing the institutions of the West need not stand in the way of eventual national reunification. European integration and reunification were not contradictory, he claimed, but rather "two sides of the same coin." ${ }^{49}$ Kohl was not the first or only German politician to make this claim (indeed, he borrowed the line about the coin from Konrad Adenauer). But it is Kohl's historic accomplishment that, in a moment of uncertainty and opportunity in 1989-and only a few months after his own party had seriously considered replacing him-Kohl seized the opportunity to do exactly what he had always advocated.

Through creative negotiations, he achieved a goal taken directly from Adenauer's playbook: reunification in peace and freedom, with united Germany still a member of both NATO and the European Community. He promised that this new Germany would not detach itself from the West, and he maintained its commitment to Franco-German cooperation within Europe. By the end of his chancellorship, he was even prepared to sacrifice the deutschmark, the symbol of German recovery and stability, in the name of European integration.

It is possible, even likely, that any chancellor serving in the 1990s would have made many of the same choices that Kohl did. But his consistency that decade in pursuit of both reunification and European integration was remarkable. Was his commitment to reunification and European integration visionary, or just the result of an unwillingness to imagine alternatives? An honest assessment has to conclude that his commitment sprang from both impulses - and therein lies the paradox of Helmut Kohl, as well as his historical significance.

\footnotetext{
${ }^{49}$ Kohl, Aus Sorge um Europa, 119.
} 
Even the greatest political career can end in failure, sooner or later, and Kohl's was no different. After his triumph in the federal election of 1990, he made the mistake of staying in office too long. Instead of seeing his narrow reelection in 1994 as an invitation to plan a graceful retirement, he proved unable to make the transition to elder statesman. Ignoring the lesson of his political idol, Adenauer, he refused to hand over the reins to a designated successor during his final term, unwisely insisting on standing for election one more time in 1998, when he suffered an embarrassing defeat. Then came the exposures of the fundraising scandal that cost him both his position as honorary chair of the CDU and, for a decade or so, his reputation as well. His personal life turned out to be far from the kleinbürgerliche Catholic idyll suggested by campaign propaganda, laid bare by his first wife Hannelore's tragic illness and, after her death, by subsequent conflict between his second wife, Maike, and his sons. By the time of his death in 2017, his reputation had recovered enough for him to be celebrated as a great European statesman, complete with a solemn ceremony in the European parliament in Strasbourg attended by a glittering list of past and present world leaders.

Democratic politics can be dull, and democratic politicians often escape the notice of historians more interested in analyzing the sensational and appalling acts of dictators and demagogues. Kohl's career is a reminder that the apparently dull mechanics of democratic politics can also produce revolutionary change. One anecdote illuminates this aspect of Kohl's career. In the 1976 Bundestag elections, Kohl led the Union parties to the brink of an absolute majority, but failed to become chancellor when the Free Democratic Party (FDP) which Kohl had been courting ever since his next-door neighbor, Hans-Dietrich Genscher, had become its chair in 1974-declined to change partners. Kohl's colleague and rival, Christian Social Union (CSU) Chair Franz Josef Strauß, who considered Kohl his intellectual and political inferior, chastised the CDU leadership for placing too much emphasis on centrist appeals to the FDP and for being lukewarm in pursuit of more conservative voters, who might have made the difference in winning an absolute majority. Strauß had long complained about CDU fecklessness, but now decided to do something about it. At a special CSU conference held in Kreuth in November 1976, Strauß announced a decision to break the existing relationship between the two parties. Although he did not lay out a specific strategy for the future, the implication was that the CSU would expand beyond Bavaria and present itself bundesweit as a more conservative alternative to the CDU, which could continue to pursue its centrist agenda.

Kohl's response to this challenge was to do nothing. In the middle of a protracted effort to modernize the CDU as a party of the democratic center, and committed to maintaining the existing relationship with the CSU at the national level, he refused to negotiate the terms of divorce. In order to keep up pressure on Strauß, he did not stop subordinates from speculating about plans to extend the CDU into Bavaria, but avoided making firm statements on that score as well. As the public debate mounted, and Kohl refused to rise to the bait, Strauß became increasingly agitated, leading to his unannounced arrival at a meeting of the CSU youth wing in Munich in late November. In the back room of one of the Wienerwald roast chicken restaurants owned by his old friend Friedrich Jahn, Strauß unleashed a furious, unhinged (and probably unsober) tirade - which soon found its way into the pages of Der Spiegel. The speech was classic Strauß, full of biting lines and Latinate insults. In attacking the "political pygmies ... vest-pocket dwarves, Reclam-edition politicians" of the CDU, his main target was Kohl himself. As he told his undoubtedly shocked audience, 
Kohl was "completely incapable" of being chancellor, possessing neither the "character nor the intellectual or political necessities" for the job. Kohl "will never be chancellor," and when he turned ninety, Strauß needled, "he will write his memoirs: 'I Was Chancellor Candidate for Forty Years: Lessons and Experiences from a Bitter Epoch.' The last chapter will probably be written in Siberia or someplace like that." 50

Revelation of the speech embarrassed Strauß, but did not shake Kohl's resolve to ride out the crisis. Rejecting even the arguments of those within the CDU who claimed that separation from the Bavarians would be good for the party, Kohl argued that the best decision going forward was to maintain the status quo. He stared down the CSU leader-and won. The Union parties remained united in the Bundestag. And after making the practical decision to endorse Strauß as the Union's candidate in the 1980 elections, a move virtually destined to fail, Kohl reclaimed his leadership position — and then proved in the 1982 Wende that it was indeed possible for the FDP to change partners. Although Strauß offered occasional challenges later on, Kohl had asserted his superior position and was able to endure whatever rough weather might come up from Munich.

The rest of the story is familiar: Kohl not only became chancellor, but also held the job longer than anyone else has (so far). In a notable historical irony, reunification became official on October 3, 1990, the second anniversary of Strauß's death. Kohl did eventually write memoirs - three volumes that carry the dull title Erinnerungen. ${ }^{51}$ Yet, before those more polished books were published, Kohl had already released a collection of reminiscences as a kind of pre-memoir: written in Kohl's suburban home in Oggersheim, not Siberia, they were titled Ich wollte Deutschlands Einheit. ${ }^{52}$

\section{Responses}

\section{Kristina Spohr}

I have enjoyed reading these diverse and thought-provoking essays, but note that most of them focus more on the second Helmut: Chancellor Kohl. Picking up on that, I would like to make a few observations about reunification before reflecting more generally on the personalities and legacies of both Schmidt and Kohl. As several of the authors note, Helmut Kohl had a strong grasp of German history. Christian Wicke emphasizes Kohl's deep sense of (liberal) nationalism and his understanding of how Germans commemorate their national past. Ronald Granieri speaks of the primary goal that Kohl achieved, namely, "reunification in peace and freedom," as something "taken directly out of the Adenauer playbook." Indeed, for Granieri, "it was precisely his lack of imagination that led to his greatest accomplishments." Similarly, Mary Sarotte says that Kohl contained the "nationalist moment inside the existing transatlantic framework," in a strategy not of "innovation" but rather "prefabrication." She is critical of Kohl for choosing to prioritize speed and

\footnotetext{
${ }^{50}$ Horst Möller, Franz Josef Strauß: Herrscher und Rebell (Munich: Piper Verlag, 2015), 518-19. See also Schwarz, Helmut Kohl, 222

${ }^{51}$ Kohl, Erinnerungen.

${ }^{52}$ Helmut Kohl, Ich wollte Deutschlands Einheit (Berlin: Ullstein, 1996).
} 
the "mechanical extension of existing formulas and structures" over negotiating new, potentially pan-European structures of political order.

Certainly Kohl had a keen sense of the past, and he aspired to grab the mantle of historyin the Bismarckian tradition - to unify his country. But he also appreciated the need for speed to exploit a very narrow window of opportunity, taking account of the fortuitous conjunction of George H. W. Bush's support and Mikhail Gorbachev's acquiescence. Kohl was also a tactile politician, sensitive to the public mood. He may have unveiled his Ten-Point Plan for unity in the Bundestag in Bonn but, as he admitted in his memoirs, it was when he encountered the surging crowd at Dresden airport in the GDR on the cold winter night of December 19, 1989-thousands of people amid a sea of black, red, and gold flags - that he really got the point: "It suddenly became clear to me: this regime is finished. Unification is coming!" 53

In short, Kohl was not simply directing events from above but also going with the flow from below - responding to the will of East Germans in the streets, expressed in that momentous vocal transition in fall 1989 from Wir sind das Volk (we are the people) to Wir sind ein Volk (we are one people) —and then, in early 1990, to that jocular threat: Kommt die D-Mark, bleiben wir. Kommt sie nicht, gehen wir zu ihr (If the DM comes, we stay here. If she won't come, we go to her). If the absorption of East Germany into the Federal Republic was a "prefabricated" option, then it was one the people also demanded for themselves: Kohl did not force it on them. And, with his acute sense of timing, he knew that a pan-European architecture-touted, among others, by Gorbachev and Genscher-would, like the Helsinki Final Act of 1975, take years to construct. One can see 1989-1990 as a wasted opportunity because of clinging on to the past. Or, one might see it as an opportunity seized in a briefly favorable moment. Much depends here on larger judgments: about how malleable politics really are, about how much freedom of maneuver political leaders really enjoy.

One final comment: In estimating the place of chancellors in history, we also have to identify their own sense of place. In other words, where they came from geographically influences, to a significant degree, where they tried to go historically. Schmidt and Kohl, as all the contributions underline, were both staunch German patriots, pained by war and by division. And, as Mathias Haeussler and Clay Clemens remark, they were also internationalists, committed to both European integration and the Atlantic alliance. But the chancellors engaged with these issues from somewhat different outlooks: Kohl's internationalism was rooted, like Adenauer's, in his Rhine Heimat, on the historic borderlands of France and Germany, and amid the rich heritage of Catholic Christendom. Schmidt, by contrast, was a lapsed Protestant from Hamburg - a port city, open to the oceans and to the world. His more global outlook was not entirely surprising.

The two state funerals captured this contrast. Kohl was buried as an honorary citizen of Europe, his coffin draped in the EU flag in Strasbourg and then carried down the Rhine to Speyer. This has been noted by several participants in this forum. But what distinguished Schmidt's funeral in Hamburg was the eulogy by his old friend Henry Kissinger, who dwelled on Schmidt's truly global network of political friendship, which encompassed not merely European statesmen like Giscard d'Estaing, but also such diverse figures as George Shultz in America and Lee Kuan Yew of Singapore. The former US secretary of state also

\footnotetext{
${ }^{53}$ Kohl, Erinnerungen, 2:1020.
} 
lauded the late chancellor's concern for and interest in "all the regions of the world." Two different funerals, two different lives.

\section{Christian Wicke}

$\mathrm{I}$ $\mathrm{T}$ is fascinating to see how strongly the authors in this forum engage with the public images of these two political leaders. Biographers are agents in the construction and reproduction of such images. Subject and author enter a dialogue as biography and autobiography, i.e., external depictions and self-images interact, mutually reinforcing each other in a communicative discourse. Biographers often choose to write about persons whom they admire, driven by an interest in particularly positive historical examples. Historians may thus risk the danger of engaging with a historist heroism: positively portraying outstanding individuals posing in front of a less positive and instable historical background.

Kohl's public image has not been predominantly heroic, however. And it is unlikely that the second Chancellor of Unity will go down in German mythology the same way that Bismarck did more than a century ago. As Granieri points out, Kohl has often been underestimated and he was "far from perfect." In contrast to Schmidt, whom Spohr represents in a comparatively positive light, Kohl's image remains highly contested, even though he worked equally hard at burnishing it. Schmidt has been perceived in the past few years as the intellectual and metropolitan "mind" of the republic, whereas many have continued to see Kohl as a stubborn provincial. Kohl's constant nourishing of that provincial image, which was part of his (self-)representation as the verkörperte Entwarnung, did not necessarily have the desired effect, then.

Clemens refers to "a certain idea of Europe" that Kohl believed in, and this idea was closely connected to his romantic notion of Heimat, consisting of cultural entities that existed within the nation but that also transcended the nation. The provincial, the German, and the European were, to Kohl, mutually constitutive. Not everyone supported this idea, of course, as Haeussler and Spohr correctly observe. In 1989, Thatcher's visit to Kohl's home region clearly demonstrated that he did not entirely succeed in solving the tension between his self-representations as provincial German and great European, and that neither category is necessarily desirable to everyone. As Spohr reminds us, Thatcher cuttingly remarked on the way home, "My God, that man is so German." Sarotte's conviction that Kohl's ability to unify Germany by reproducing the Western system of the Cold War within a new context-and thus contain German nationalismsuggests, by contrast, that he somehow succeeded in his quest for normality. Several authors also mention Kohl's willingness to give up a major national symbol - the deutschmark-a decision that might further sustain his anti-nationalist image. But that only holds true if we ignore the fact that nationalism is an adaptable and "parasitic" phenomenon dependent on other identities, including regional and supranational ones, as well as on ideologies like conservatism and liberalism. ${ }^{54}$ Being a strong supporter of European integration does not necessarily conflict with, but can instead be constitutive of, particular kinds of nationalisms.

\footnotetext{
${ }^{54}$ See, e.g., Michael Freeden, "Is Nationalism a Distinct Ideology?," Political Studies 46, no. 4 (1998): $748-65$.
} 


\section{Mary Elise Sarotte}

I

$\mathrm{N}$ reading this extremely interesting collection of comments, I am struck by the fact that four of us - Clemens, Granieri, Wicke, and I-all independently chose to emphasize Kohl as a figure of continuity. This view contrasts with the still popular notion that there was, on his watch, a dramatic change at the domestic level and the creation of a "new world order" on the international level. The belief that a "new world order" emerged is surprisingly durable, despite the renewal of Cold-War-esque tensions between the West and Moscow in recent years. As I argue in my initial comments, a new world might have emerged in the revolution from below that took place on the streets in 1989, but no comparable new world order emerged in the subsequent reaction to those events from above. It was therefore particularly interesting to see the other authors independently make similar arguments based on different examples from foreign and domestic policy.

\section{Ronald Granieri}

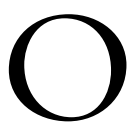
NE of the interesting aspects of the foregoing comparison of the "two Helmuts" is the realization that historical significance can be so tied up with circumstances beyond the control of historical actors. Historians who take the (perfectly defensible) position that Helmut Schmidt was objectively a better qualified chancellor than Helmut Kohl end up sighing that the combination of internal SPD intrigues and FDP perfidy robbed him of his chance to achieve greater historical accomplishments. It is a small step from there to wondering how much better he would have handled the German-German diplomacy of 1989-1990, or to grumbling that Helmut Kohl simply lucked into his moment in the sun. As I suggest in my contribution, and as Mary Sarotte notes as well, Kohl did not present any innovations in 1989, but rather relied on the tried and true. Would the brilliant Helmut Schmidt have been able to offer something new and different? Was something new and different at all possible? We will never know, and Schmidt's advocates can blame a long list of his colleagues (both within his own SPD and in rival parties) for depriving him of the historical chance to teach us otherwise.

These are no small considerations when reflecting on the challenges of national leadership in a democratic polity. After all, one can only do great things if one is able to get into and stay in office. Electoral success and coalition management depend upon, frustratingly enough, more than having the most impressive resume. Cutting an appropriate public figure matters quite a bit, but here as well Helmut Schmidt reminds us that even the most urbane presentation on the international parquet (or the most metaphorically ideal selfpresentation as a capable helmsman) is no guarantee of longevity in office. It is ironic that Schmidt's carefully cultivated centrism, which allowed him to win elections in 1976 and 1980, also eroded his reputation among the SPD rank and file; it also contributed to the lack of internal support that cost him his job.

Helmut Schmidt did face crises while in office on a variety of levels-from the economic stagflation of the late 1970s, to the violence of the German Autumn and the hijacking of Lufthansa Flight 181, to the declaration of Martial Law in Poland in December 1980- 
and he rose to every occasion. He was creative in his responses, forging a partnership with Valéry Giscard d'Estaing that helped create the G7, rolling the dice on sending the elite unit Grenzschutzgruppe 9 (GSG 9) to Mogadishu. He also displayed a cool head when necessary, such as when he refused to allow the Polish crisis to disrupt his careful ongoing efforts at German-German détente. It adds up to a record that would earn any chancellor an honored place in the history books.

And yet: those accomplishments, all in the service of promoting international and domestic stability, were essentially conservative. It is one of the fascinating aspects of the 1970s, a decade in which many social and geopolitical transformations began, that the leaders of the so-called great powers achieved their greatest accomplishments in maintaining the status quo. The Strategic Arms Limitations Treaty (SALT) and the Commission on Security and Cooperation in Europe (CSCE) were transformative in the long run, and they no doubt contributed to the Wende in 1989-1990. Those talks, however, were not on the same dramatic grand scale as Kohl's diplomacy after November 1989, or even Willy Brandt's dramatic opening gambits in Ostpolitik. Nor were they necessarily meant to be. From the 1970s to 1989 , conventional wisdom held that maintenance of a divided world was the best one could hope for, whereas speaking of transcending the Cold War order was considered to be irresponsible, unrealistic, and dangerous. Only in retrospect does the path from Helsinki in 1975 lead directly to Berlin in 1990. Such paths are hidden from contemporaries, even from such wise and thoughtful statesmen as Helmut Schmidt.

Schmidt stayed in the public eye and remained engaged in every significant debate over the remaining four decades of his life thanks to his position at Die Zeit and to his status as an elder statesman, but that was not quite the same thing as wielding political power-something he knew as well as anyone. He was not the only brilliant geopolitical thinker of the 1970s who found himself on the outside looking in by 1989: Richard Nixon and Henry Kissinger, who also considered themselves great strategists, were reduced as well to writing admonitory essays in opinion journals, as Ronald Reagan and George Bush, two men whom they considered to be their political and strategic inferiors, earned international plaudits for bringing the Cold War to (what appeared to be then, at least) a successful conclusion.

Helmut Kohl had much better political luck on his side. He survived the most serious challenge to his leadership in September 1989, in part because of international events. An internal rebellion had been planned by his colleagues Heiner Geißler, Lothar Späth, and Rita Süssmuth at the party convention in Bremen. They hoped to depose Kohl as CDU chair in preparation for the next elections, scheduled for 1991. But at the opening press conference in Bremen, Kohl was able to announce Hungarian Prime Minister Gyula Horn's decision to allow East Germans seeking refuge in the West German embassy in Budapest to leave for the West, deftly using this diplomatic success to disarm his critics. Three months later, Kohl was on track to be the Chancellor of Unity, and his critics (with the notable exception of Geißler) made their peace with his continued leadership.

Kohl's political decline was more gradual, but even more decisive, than that of Schmidt. He failed to recognize the signs of the times and could not bring himself to give way gracefully to a successor. Eventually, even he had to bow to the iron logic of democratic politics, becoming the first postwar German chancellor to lose his majority thanks to an election rather than to the sort of coalition tango that had brought down Helmut Schmidt. Schmidt's chancellorship fell victim to a dramatic assault; Kohl's succumbed to a lingering 
malaise. Both are quintessentially democratic political fates, reminders of the old British adage that every political career ends in failure.

Could some sort of external crisis perhaps have saved Helmut Schmidt's position in 1982? It is impossible to say, of course, and even harder to imagine what kind of crisis would have been necessary to reverse the political tide running against him. But recognizing the interplay between domestic political wrangling and geopolitical strategizing, between the requirements of a politician and the aspirations of a statesman, is crucial for understanding the complexity of leadership in a republic. Any elected leader is, in the end, only as strong as that leader's ability to mobilize the electorate, and any leader's historical reputation depends on the vagaries of politics at home and abroad. The intertwined fates of Helmut Schmidt and Helmut Kohl certainly teach us that.

\section{Mathias Haeussler}

$\mathrm{T}$ wo main points emerge in the highly stimulating contributions to this forum. In the first place, most contributors tend to focus on the two Helmuts' international roles, rather than on their domestic legacies. Second, they all address issues of continuity and change. The picture that emerges with respect to foreign policy, particularly in the contributions by Sarotte and Clemens, is, by and large, one of continuity: for much of their time in office, both Schmidt and Kohl usually took the road more travelled. But, to turn Robert Frost on his head, that choice may have made all the difference. Divided and semi-sovereign postwar West Germany always had precious little wiggle room, despite the country's postwar economic ascent and the occasionally pushy personal diplomacy of Schmidt and Kohl. Until the late 1980s, the primary goal was to consolidate their predecessors' main achievements in the face of a rapidly deteriorating international environment in the late 1970s and early 1980s. Adenauer's Westpolitik had tied the Federal Republic firmly to the West, whereas Brandt's Ostpolitik had opened up doors to the East; the two Helmuts then spent much of their time in office trying to preserve and strengthen these two pillars of diplomacy. This certainly did the Federal Republic no harm, particularly in light of the country's unique historical burden and the widespread distrust that it awakened in Europe and beyond. Indeed, as Granieri suggests, Kohl's "lack of imagination" in 1989-1990 may have actually been his greatest asset: by resorting to the country's tried-and-true Cold War success formula, it helped calm widespread suspicion abroad about the future character of, and potential challenges posed by, soon-to-be unified Germany.

The real historical caesura, then, seems to be, on the one hand, the end of Europe's bipolar Cold War order and the reunification of Germany, and, on the other, the way in which crucial decisions taken in 1989-1990 affected West Germany's power and international position in the long run. This leads to the intriguing counterfactual that Granieri brings up: would Schmidt, had he still been in power, have acted much differently. I am not so sure. Schmidt - every conservative's favorite Social Democrat, after all-had always been eager to guarantee the continuity and reliability of West German foreign policy, particularly during the "re-heating" of the Cold War in the late 1970s and early 1980s. Among his favorite buzzwords were "steadiness," "stability," and "predictability"; his long-standing personal feud with Jimmy Carter was, after all, a partial result of what he regarded as "fickleness" and seemingly erratic diplomatic behavior on the part of the 
American president. ${ }^{55}$ Even the key foreign-policy legacy of his chancellorship-NATO's "dual-track" decision-was essentially a reactive one: to preserve and restore the military balance between East and West, at a time when most of his party base appeared to be much more concerned about the growing North-South divide. If one interprets the rearmament debates of the early 1980s more generally as symptoms of a gradual erosion of the binary logic and societal cohesiveness of the Cold War, then Schmidt actually emerges as a gatekeeper to the "old world" rather than as a particularly innovative or creative foreign policy maker. ${ }^{56}$

How, then, would Schmidt have reacted to the seismic shifts of 1989 and beyond? Would he have "better" prepared Germany for the globalized, multipolar world of the twenty-first century? Would he have opted for a genuinely pan-European security system, rather than for an eastward extension of NATO? This is doubtful, though I certainly agree with Kristina Spohr that Schmidt grasped the implications of the 1970s wave of globalization earlier and perhaps more fully than most of his contemporaries. But the institutions and policies that he helped shape in response were still based largely on "small-c" conservative instincts: to preserve and protect the existing Western order against these new global challenges. The G7 world economic summits, for example, were a fairly exclusive gathering of the West's most industrialized countries, not a genuinely global forum for macroeconomic coordination. Schmidt's stubborn and single-minded pursuit of the "dual-track" decision similarly revealed the continuing dominance of East-West bipolarism in his geostrategic thought, whatever longer-term preoccupation with the rise of China he might have had.

Although it might be seen as a moot point, I therefore doubt that Schmidt's role in 1989-1991 would, in the end, have been much different from that of Kohl. But this should come as no surprise. Statesmen deal primarily with what they perceive to be the political realities of the day, and both Helmuts proved extraordinarily skilled in that regard. In so doing, they were, as Granieri and Spohr rightly highlight in their responses, driven as much by external constraints and domestic circumstances as by their personal instincts and "grand designs." In 1989-1990, all these factors pointed toward sticking to the Federal Republic's postwar "success formula" of predictability and pronounced multilateralism, rather than the pursuit of an adventurous (and likely unilateral) quest for a pan-European security system. The two Helmuts were thus, in this sense, both products of the very particular historical context of Cold War West Germany-an artificial and provisional construct that has now, like the two Helmuts, faded into history.

\footnotetext{
${ }^{55}$ Helmut Schmidt, Menschen und Mächte (Berlin: Siedler Verlag, 1987), 224.

${ }^{56} J a n$ Hansen, Abschied vom Kalten Krieg? Die Sozialdemokraten und der Nachrüstungsstreit (1977-1987) (Berlin: De Gruyter Oldenbourg, 2016).
} 